\title{
Environmental Communication Instruments for Environmental Policy Integration
}

\author{
Erika Lagzdina, The Regional Environmental Center for Central and Eastern Europe (REC)
}

\begin{abstract}
Two public policy concepts -- modernization of governance and environmental policy integration - serve as the basis for this work. The author links them up with environmental communication (EC) as an integration instrument approach, and tests application at the local level in Latvia. Totally 30 case studies were analysed and survey methods used to interview over 70 people. The article verifies driving forces affecting the internal and external integration of environmental policy, explicates EC instrumentality for integration by assessing policy instruments and stakeholders. The final conclusions affirm that, in order to integrate environmental management into municipal development, it is necessary to establish a complementary set of policy instruments, what might be enabled by wise use of all EC components in their interactivity. The complementarity of EC instruments and stakeholder group efforts forms synergy and enhances better environmental policy integration.
\end{abstract}

Keywords - Collaboration, environmental communication, environmental policy integration, policy instruments, municipal development, stakeholders.

\section{INRODUCTION}

Two approaches characterizing public management processes nowadays: modernization of governance and environmental policy integration establish a conceptual basis for our research. The first concept aims at better public management methods, tools and policies, as well as higher quality services to the public, second - at integration of environmental concerns into sectoral policies and governance, which implies integration of environmental goals, instruments, and stakeholder or target groups.

The response to what makes the practicality of environmental integration and how on-going governance reforms may interact with environmental management mutually benefitting, is addressed by the author in this article in trying to assess processes at the local level. Generally, the modernization concept includes policy making based on goals and results, not existing structures and functions, besides it means inclusive policy making supported by a broad debate in different society target groups. It implies the vertical and horizontal integration of policies, programs, governance levels and sectors. Modern management strives towards excellence, which is to reflect the dominant values and priorities of society, besides it is characterized by communication elements (informing, creativeness, transparency etc.).

The selection of the local level to study integration is justified by the fact that, ultimately, all policies end up at the local level, and environmental management responsibilities are a particular example of that. We ground our considerations on principles of sustainable development (SD): requesting integration of social, economic and environmental spheres of life; emphasizing the role of local level in addressing environmental concerns; and the need for stakeholder involvement to implement SD. In addition, we utilize education and information imperatives recognized as the basic preconditions for SD [1].

We argue that the pre-requisite for effective policy integration is a well established sectoral policy that requests a profound disciplinary understanding of environmental sector management through the implementation of a full management cycle, represented by the so-called 4P model: P1 means problem evaluation and opportunities identification; P2 - policy design that implies a vision statement, a declaration of principles and policy goals; P3 policy planning that identifies targets and selects appropriate policy instruments; P4 - policy implementation which involves programming of concrete actions, resources and use of indicators for the evaluation of results, finally - return to the initial stage of situation assessment.

The majority of local governments still cannot find a suitable framework to accommodate sustainable management processes, as a result environmental management and integration is suffering as well. There is a lack of widespread awareness of Local Agenda 21 (LA21) process benefits in Latvian municipalities. Only a few municipalities are participants of international networks, which are creating knowledge and offering models for merging environmental management and governance approaches. National policy framework and legislation are reference points for local politicians' decisions in regard to environmental management and planning [2, 3]. We shall use existing processes and tools, and take advantage of positive interaction between external driving forces and internal (municipal level) factors to build new approaches for sustainable local management with a view to better environmental integration. We shall rely on the interests and concerns of each individual and sector for good environmental quality and sustainability to provide what is essential for local development ecosystem services and to integrate stakeholders through environmental communication (EC) instruments.

Four components of the EC model (environmental information, environmental education, public participation in environmental decision making and behaviour in environmentally friendly manner) applied complementary become indispensible elements of environmental management processes in all environmental subsectors (water, waste, air, nature etc.) and spheres of life: at work, home and study. Thus we shall bring them to a new 
development level and use as an integrative tool for overall development processes. We believe that environmental communication might build the most efficient unifying communication and collaboration medium for multilateral discussions and the integration of different stakeholders, and sectoral interests with view to sustainable development and environmental integration as a primary step. This conceptual approach of using EC and its four components as instruments for environmental integration is offered for discussions and further studies.

\section{METHODOLOGY}

The article summarizes selected findings of wider research activities performed in the frame of $\mathrm{PhD}$ thesis writing and implementation of a project: ,Environmental communication instruments for environmental policy integration" done by two organizations: The Regional Environmental Center for Central and Eastern Europe (REC) Country office in Latvia and the University of Latvia. It was co-financed by the European Economic Area grant and support from national "Environ-mental policy integration programme". The project was implemented by a team of environmental science doctoral programme students and academic staff from the Department of Environmental Management (DEM). It utilizes environmental communication and collaboration communication concepts and methodological tools developed and adapted during many years of field studies in numerous municipalities (Liepaja, Pavilosta, Ventspils, Kolka, Dundaga, Roja, Carnikava, Saulkrasti, Salacgriva, Ainazi, Cesis, Livani) [4, 5]. The research builds on findings of previous studies and adds new empirical data, covering a total of 30 municipal case studies.

The research forms three blocks: 1) environmental management assessment on the local level with a focus on environmental policy planning and instruments; 2) environmental communication (EC) disciplinary assessment from the perspective of instruments and target groups; 3) assessment of policy integration frameworks and practical implementation at the local level, focusing on integration processes. Assessment of two first blocks gave us a set of driving forces enhancing environmental management in Latvian municipalities and revealed their interlinkage to set up optimal preconditions for developing the municipal environmental management as a disciplinary sector. It forms a basis for discussions on the intermediate value of disciplinary planning towards integrated planning. Detailed studies of EC presented an opportunity to collect numerous single, nonrecurring case studies forming quite a comprehensive picture of the EC situation in Latvia today, and allowed to form a complete EC management cycle model. The research itself is a substantial contribution to the EC studies discipline development in Latvia.

The research was conducted using a complementary set of qualitative research methods applied in a harmonized manner. The case study method was selected as the most appropriate for the particularly unique, statistically unqualified situations description. The document studies involved academic literature, policy and legal texts, media studies, as well as project reports etc. The internet research was an important information source. Special attention was paid to municipal website analysis as potentially the most important communication channel with a view to emerging municipal marketing strategies and e-governance elements. The survey method was the prevalent method used to solicit expert views. Experts were selected in all research fields for structured face-to face interviews, they represented management areas and EC components -- all target groups. Group interviews and focus group seminars were selected as a method for sector analysis: environmental education, NGOs sector, local level integration. In total, the research involved over 70 persons as information sources.

\section{RESULTS AND DISCUSSION}

\section{A. Municipal environmental management: external} driving forces and internal factors

The research was conducted through interviewing 30 municipals specialists and using earlier project reports allowed to indentify the most important driving forces influencing the development of the environmental management experience at the local level:

1. Rio de Janeiro conference on sustainable development in 1992 invited local governments to start the Local Agenda 21 (LA21) process - development planning integrating environmental, economic and social goals and involving all major stakeholder groups at the local level. Most municipalities understood it as a signal for a more profound formulation of their environmental goals and action plans. For some environmental planning there was an urgent need due to bad environmental conditions and public pressure, for others- it was the exposure of politicians' maturity to recognize the need for a new type of strategic planning based on dialogue and public participation, thus giving the essential political support for process initiation. Unfortunately, a majority of local governments in Latvia did not react to this call for action.

2. A number of cooperation projects with foreign partners, especially from Scandinavian countries, in the late 1990-ties allowed the most active municipalities (cities: Jurmala, Cesis, Liepaja, Ventspils, Rezekne, Daugavpils; and some rural communities in Liepaja, Talsi, Jekabpils and Aluksne districts) to develop their human capacity and to start LA21 processes, which resulted in the first environmental policies or environmental action plans at the local level. However in most cases we shall acknowledge the indispensable role of the personally motivated municipal staff. The Rio call to national governments to facilitate LA 21 process, in Latvia did not work, and there were no clearly identifiable driving forces at the national level in 1990-ties promoting environmental management at the local level: neither binding laws, nor financial instruments.

3. The EU approximation process until 2004 revealed much environmental non-compliance in most of the municipally governed environmental sectors (waste and water management as the most critical ones). The need for urgent reaction was the reason for the national government to centralize environmental policy planning and 
implementation, through nationally driven sectoral programming and financial management. Only a few municipalities exercised local planning and some of them (in Jekabpils and Aluksne districts) used the LEAP methodology - the approach of local environmental action planning promoted by the REC projects across Central and Eastern Europe (CEE), enhancing tools for the collaborative priorities setting process and local partnerships. As a result, during the last decade the number of local environmental policies did not boost, and today we can count less than $5 \%$ of municipalities have their own disciplinary environmental policy documents [2]. Few of the existing plans will be renewed after their expiry period due to a change in the situation: in some municipalities environmental quality improved and overall good performance is stabilized in all sectors, and thus new plans won't be needed, others prefer a shift to the integrative development planning.

4. EU membership is an external driving force for the last 5 years shaping municipal environmental management in the context of the EU sustainability and environmental policies. This brought up urban strategies supporting integrative planning. It resulted in 16 municipal development strategies in Latvia which integrated sectors, levels and time scale. The analysis shows that the quality of environmental integration in new strategies is quite different due to an unstandardized methodology and the municipal environmental disciplinary planning experiences of the past. For example, the Jelgava municipality which went through all the steps of environmental management capacity development (starting with bottom -up LA21 process in the early 1990-ties, followed by top-down Municipal environmental policy plan and action program for 2003-2007, implementation of IS0 9000 management quality standard) demonstrates a high level of environmental integration in its new strategy.

The difference in how environmental management and planning is developed is shaped by the local cultural context and internal factors:

1. The local environmental situation and political support were already mentioned as important factors. They involve elements of local policy style which might be open and inclusive as regards the involvement of all stakeholders and municipal department, or opposite.

2. Explanation on why environmental planning is not wide spread is related to human and institutional resource factors. Professional staff availability and environmental departments exist in a marginal number of municipal administrations (for example, departments work in: Liepaja, Ventspils, Jurmala, staff in: Jelgava, Cesis, Rezekne, Daugavpils, Valmiera). The tendency in the last years shows that the environmental sector is integrated in communal or project departments, that in some cases brings positive effects, in others- reflects the weakened position of environmental goals in front of other development needs. The low competence of staff in environmental matters can be explained by the lack of a specific staff position for this purpose and also due to a passive interest in the "soft" project developing tools and mechanisms for better governance and environmental management offered by the numerous EU level projects and lead by recognized academic institutions and international municipal networks (like ICLEI, UBC). Our municipal administrations prefer to work with infrastructure investment projects. Nonetheless there are findings from other projects which underline that environmental problems cannot be solved only by investments, and that public awareness raising is an important prerequisite for achieving environmental goals at all levels [6]. The instruments for environmental awareness raising are explicitly related to information and education as the most important components of environmental communication.

3. The level of local public environmental awareness depends on many factors (like the availability of information, compteneces, as well as environmental quality in the municipality). Awareness is manifested in different ways. The environmental concerns of non-governmental organizations (NGOs) and citizen pressure groups are articulated in different media and forms and thus create a bottom-up force influencing a municipality's environmental performance. In Latvia public pressure is an advancing factor for development of environmental management though it is not a crucial one due to low self-organization of local stakeholders and thus limited cases create the necessary evidence for this interlinkage.

We stated that the development of environmental management at the local level takes place in a wider international and national context. We can say the same about the development of new policy instruments. The need for new policy instruments in the environmental field to replace or supplement traditional control and command instruments, is discussed by many authors [7, 8].The driving forces for the creation of new policy instruments are:

- new type of relations between society and the state, based on voluntary principles;

- development of democracy, which includes concepts of environmental rights, including access to environmental information, environmental justice, public participation,

- new public management approaches including principles of subsidiary, integration, participation and inclusiveness $[9,10]$.

The assessment of environmental management practices at the local level shows that instruments represent mostly traditional regulatory and control instruments. Unlike many other countries in the world, Latvian municipalities have limited rights to introduce local instruments, especially economic ones. Environmental budgets are formed from the revenue from natural resources tax (NRT) In many municipalities, the proportion of NRT $(60 \%)$ redistributed from the national budget, is their only resource for environmental management. Planning and strategic environmental assessments (SEAs) are the most frequently used and thus most powerful local instruments for environmental policy integration. Therefore, participation and collaboration based planning is the main direction where we seek for improvements to reach the goal for integration of the environment in local development processes. The planning process and the SEA provides a platform for the discussion and consensus building of diverse interests, and 
the wise application of environmental communication instruments play an important role here.

\section{B. Environmental communication: development, instruments and target groups}

Environmental communication (EC) experience can be created in local circumstances; however we cannot deny the importance of the national EC development context as a driving force for local processes. In our research we tried to identify, what is the status and potential of the development of EC as a policy instrument in Latvia generally and what are the forms and content of the EC. This led us to reconfirm the importance of target groups and EC components defined already in the first national level document "Environmental communication and education strategy" (2001) and reaffirmed the relevance of the EC model consisting of environmental information, environmental education, public participation and environmentally friendly behaviour.

Looking back in the history of the last two decades we conclude that development of environmental communication different components in Latvia was influenced by two major trends:

1. One - stemming in academic and practical studies of environmental education (EE) in the 1990-ties initiated as bottom-up process from two NGOs (University of Latvia Ecological Club and Children Environmental School) and resulting in the formalization of environmental education as an interdisciplinary subject through EE guidelines for the primary school level (1996). This gave rise to the extensive development of teaching materials for $\mathrm{EE}$ and especially non-formal education activities performed by schools and NGOs.

2. Other - deriving from international political processes: the sustainable development process (Rio) (1992) and the Aarhus Convention (1998), both putting unprecedented emphasis on public environmental rights of access to environmental information and public participation. Those processes influenced all parties in the environmental sector:

- general public and its most active part - environmental NGOs requesting rights to live in a qualitative environment, more access and transparency in environmental matters,

- public governance bodies face new duties to provide information and involve the public, to secure and react on public environmental concerns;

- business - is forced to make publicly available emission and pollution information.

The Rio process has a specific reflection also in the Baltic Sea region, resulting in the recognition of EE as a separate sector for SD processes making significant impact on educational strategies in Latvia [11]. The latest driving forces are connected with the global processes (climate change and globalization) and EU environmental and sustainable development policies calling for change in production and consumption, and emphasizing the role of each individual to change their behavioural patterns towards more environmentally friendly ones. Global circumstances request increased environmental awareness in all sectors and at all governance levels - the public included. This allows to extend traditional understanding of what makes EC content, and explicitly adds environmentally friendly behaviour as a component to complete the EC cycle to reach its ultimate goal - behavioural changes.

The efficient use of EC instruments for integration requests disciplinary understanding of this sector. To that extent, the 4P management cycle approach and instruments to link policy and implementation is a useful analytical framework. We derived from many approaches of instruments classification and grouped them into the following sets for analysis:

- policy planning and legislation instruments;

- institutional instruments;

- economic instruments;

- infrastructure instruments;

- communication instruments (involving information, collaboration and coordination).

The development of environmental policy instruments at the national level has a positive influence on environmental management at other levels and all sectors. The development of EC went quite slowly and the capacity of public bodies to use EC as a policy instrument is underdeveloped. Our finding is that policy instruments necessary for support of EC exist both at the national and local levels, though we remind that this conclusion is drawn based on a limited number of municipal case studies. Below we provide some characteristics describing these findings in a selective manner. In the article we use a mixed approach of national and local level experiences, integrating target groups in the instrumental assessment text.

We limit our description of policy and legislation instruments to the environmental sector, although one must admit that EC has to be integrated in all sectors, and there are relevant findings addressing this issue.

Policy and legislation development belongs to the P2 and P3 steps in the management cycle as described in the introductory part. The First National Environmental Policy Plan (NEPP, 1995) recognized the importance of information and education as policy instruments, though information was perceived primarily as an early warning system and a basis for environmental data. The $2^{\text {nd }}$ NEPP for the years 2004 2008 (2003) was developed with a much higher level of management competence and wider public involvement. The integration concept was introduced in the plan, and society was recognized as an important target group. Cooperation among state institutions for better integration of decisions was challenged. The nature protection sector has to be mentioned as the most advanced in terms of the use of diverse EC instruments (with emphasis on non-formal EE at all levels). However, a focus on information as the central component of communication still remains in the sectoral plans (air, climate, water, waste). The $2^{\text {nd }}$ NEPP introduced two chapters: Environmental Information and Public Participation, and Environmental Education and Science, thus emphasizing their relevance as separate environmental management sectors. On the other hand, it implies some risk of disintegration of the complementarity concept of four environmental communication components. The policy plan envisages wide institutional development through regional 
information centres, the allocation of economic and financial resources, introduction of award schemes etc. Cooperation between the state and the NGO sectors to develop life-long learning is planned. The plan can be praised as quite comprehensive and modern, although the assessment of its implementation in 2009 shows that many initiatives were not implemented fully and the evaluation of results seems is the weakest element of the management cycle at the national level. The $3^{\text {rd }}$ plan- Environmental Policy Guidelines (2009) includes the same EC subchapters as the $2^{\text {nd }}$ NEPP in the Environmental and Society chapter, thus opening "doors" to discussion of environmental problems in the social and culture context. To summarize, public environmental awareness after 10 years of environmental policy implementation is still referred as a central problem and task in the NEPP, though repeatedly the same instruments, measures and approaches are used to address it. Without reform in the EC policy planning on the national level using the disciplinary sector approach, a significant shift in public environmental awareness is unlikely.

The Environmental Protection Law (2000, 2006) shall be mentioned as the most important legislative document setting the framework for the EC: information, participation, public participation in environmental activities. It defines the obligation of the introduction of environmental education at al levels of formal education.

Looking on the local level, EC policy can be assessed in limited cases, as only Ventspils, Cesis, Liepaja municipalities have a reflection of EC in their policy documents. The Liepaja municipality in 2010 introduced new $1^{\text {st }}$ chapter Environmental communication in its renewed Environmental Action Program 2009-2014. Their approach is based on a full management cycle, EC assessment indicators included. In other cases, EC is integrated in different chapters of plans, and it has instrumental value to reach environmental goals. EC elements are recognized dispersely in different policy planning documents produced at the local level, they do not have an explicit role towards policy goals, rather they characterize unlinked among themselves EC activities. We recommend that, to improve EC efficiency either through disciplinary, integrative or mixed planning, a more systemic approach has to be applied

Environmental policy is also concisely articulated through Municipal Environmental Management Systems (EMAS and ISO) developed by few municipalities (Riga, Jelgava, Daugavpils, Preili etc.). An absolutely new approach of environmental policy is created in the development of environmental declarations. Such types of declarations in 2010 were signed by 7 municipalities in Latvia joining the Mayor Climate Convenant, but the Salacgriva Council recently announced a Green Municipality declaration with focus to renewables. Climate could become a fashion trend or PR instrument in municipal environmental communication.

Institutional instruments for EC are evaluated as structures working within environmental, education and other sectoral ministries and subordinated bodies. Communication science drives an understanding of communication, primarily information flow and, as PR instrument, limits the opportunity for governmental bodies to perform a complete communication process. Public consultative boards as an external coordinating and communication instrument between the government agencies and society groups proved to be efficient mechanisms to advance participation and education components of the EC cycle. Allocation of greater EC responsibilities to the state agencies (like Latvian Nature Museum, Nature Protection Agency) demonstrates better results, as professional staff is involved in EC planning and implementation. The strength of EE is not its integration in general educational standards, but rather EE coordinators network of 28 specialists covering the whole country and serving as an important factor to EC development and particularly EE methodological guidance for teachers trying to integrate EE and ESD in the school curricula. EE coordinators are an important link between $\mathrm{EE}$ and municipality. Their collaboration and synergic effect is seen while implementing Blue Flags Campaigns or the Ecoschool model at the local level.

At the local administrative level, EC frequently falls in the overall communication processes run by the municipal PR units, however cooperation between environmental and communication specialists is a necessary precondition for good externally orientated information flow. In the interviews conducted during this research, experienced experts from Ventspils, Liepaja and Cesis emphasized the role of environmental departments in the professional preparation of information. Looking for new opportunities we identify the Client Information Center (or One Stop Agency) as a governance modernization tool useful for EC promotion.

As it has been mentioned earlier, economic instruments for EC development stay within public budgets and grant programmes. The Latvian Environmental Protection Fund (LEPF) and similar funds, at the local level are built on revenues from the NRT and for a long time were a financial resource for EC activities and projects utilized by all stakeholders. For example, annual Environmental Days in Cesis and the Environmental Policy and Action Plan were developed with financial support from these funds. After the financial crisis in 2008, the availability of grants for EC was dramatically reduced which is an important threat to maintaining EC. Though we shall recognize that at least the national-level specialized environmental media still receive support from the LEPF, that which is important for municipalities where EC is insufficiently developed is in the local media who lack competence or interest to reflect environmental issues.

Infrastructure consists of different technical elements (web sites, infocenters, nature trails, equipment etc.), and it is relevant for the development of all components of communication. Data bases and websites are crucial for providing environmental information. The research identified that almost each public organization has a link Public Participation on its website. Many municipalities create a link Environment or Green Corner. The analysed contents are quite diverse: policy documents, publications, grant tenders, list of NGOs, projects, news, information about waste management, local regulations, links to other 
organizations etc. Some municipalities place environmental quality data (water quality during the swimming season in Blue Flag cities, air quality in Riga, Liepaja etc.). Cooperation between different sectors, especially business, nature protection territories, forestries and schools to use available infrastructure for nature communication is a positive experience indentified all over the municipalities studied.

In application of any instrument discussed above we acknowledge that communication plays a role. Collaborative communication is present in relationships between stakeholders at the local level. The importance of sharing information to enhance new information and communication has been proven while stydying cases of the Ziemelvidzeme waste management company (ZAAO) and the Latvian State Forests. The strategic goals of the companies are explicitly integrated into their communication policy which carries all components typical to EC, besides they develop approaches orientated to specific target groups (clients), which confirms that targeted communication is a key to success.

\section{Environmental communication target groups: interaction and collaboration}

Communication and marketing disciplines emphasize a selective attitude to the audience, due to different situations, perceptions, varying levels of knowledge, communication skills and needs. The environmental communication field is even more complex as it reflects interaction between target groups which, at the same time, are senders and receivers of information, or in a broader sense - creators and users of EC.

Our research distinguishes between 5 main target groups: 1) state sector, 2) municipal sector (including administration and subordinated organizations: schools, communal service etc.), 3) business, 4) local society, and 5) mediators (NGOs, science, non-formal educators, and media). Each of the mentioned target groups has certain environmental responsibilities or concerns. Using communication as an instrument enables them to communicate their goals and to interact with other stakeholders in overlapping areas. Sometimes direct communication channels, especially in topdown models, do not work properly, thus the mediator sector with its tools becomes an essential factor to overcome the communication gap.

The research identified that, regardless whether a municipality's position towards the development of EC is active or passive, there is a communicative medium where regular activities take place. Most of them might not identify themselves as specific EC orientated, though produced content allows to classify them as such. Examples are the regular communication activities (articles, leaflets etc.) of municipal communal services (water and district heating utilities) towards citizens about their work, fees, local regulations, infrastructure projects, saving measures. Many municipal companies get involved in organizing excursions for schools and even produce educational materials (examples of DVDs on water by the Ventspils water utility or Pupils' Work Books on waste by ZAAO in Valmiera). Client communication becomes an indispensible part of a company's work. More formal communication exist between state representatives in the region and other target groups, though regular information sharing and problem discussion meetings, educational seminars and participation in formal procedures are tools where interaction and integration takes place.

The EC model of the North Vidzeme Biosphere Reserve (NVBR) is the most advanced case identified by the research and it has great replication potential. A vast complex territory, limited resources, many levels of governance and disperse sectoral responsibilities create a serious management problem. Forming consultative mechanisms involving different state and local representatives, developing an interactive website, involving local people in volunteer monitoring activities, river clean-up and restoration activities, salmon saving campaigns, organizing NGO forums for the exchange of ideas, attracting regional universities research potential, building on mediation capacity of local schools and libraries for environmental information dissemination, collection and education, motivating rural small-scale business through grant schemes, demonstrating environmentally sustainable practices in forestry, tourism and building skills - this all forms diverse communication tools, platforms and user driven approaches, and provides the opportunity for all target groups in the territory to be involved in different environmental management processes according to their specific interests and possibilities. What is the most important, that there is one central driving force- the NVBR administration which keeps all processes coordinated, monitors their results and drives all processes towards the ultimate goal- the sustainable development of the territory, integrating environmental, economic and social dimensions, as well as levels and stakeholders. Similar model elements emerge in some other territories in Latvia (Kemeri National park and others).

\section{Environmental integration through collaborative planning}

The planning processes in Latvia are multifaceted as regards sectors, levels and types of documents. Until 2006 when national level Policy planning system development guidelines were adopted, there was no uniform approach to planning processes and this resulted in incomparable sectoral documents as regards their content and quality as well. Guidelines set requirements and hierarchical relationships between different planning documents. In this context, integration of national sectoral policies at lthe ocal level becomes even more challenging, and platforms for collaborative communication are of utmost importance. Apart from the spatial and development planning performed by municipal administration relatively independently, few other planning processes related to the environmental integration exist: nature protection management plans for Natura 2000 sites, river basin management plans, and landscape ecological plans. The first two are regulated by laws and the municipality is defined as one of the stakeholders in the planning exercise. On the other hand, the municipality is the most affected party, as plans include numerous local development elements: land use, allowed 
economic activities, available resources, plans for development of infrastructure. Thus the results from the planning process have an impact on many interests, and the municipality has to seek ways to coordinate those interests, maintain common interests above individual benefits, and facilitate consensus not only among different local target groups, and their neighbouring municipalities, but also vertically- with higher governance levels (regional planning agencies and sectoral ministries).

Legislation sets quite strict standards for planning processes: access to information, transparency and public participation requirements to legitimize the result. However, regulatory instruments defining formal involvement prove to be inefficient in many cases. Many interviewed people and NGOs criticize failures of formal mechanisms to ensure genuine participation and the representation of interests of all sectors and target groups at the local level.

Natura 2000 territory planning is one example where national nature protection interests frequently meet strong local level opposition supported also by local governments and lobbied by developers. We believe that strategically planned and comprehensive environmental communication involving all EC components, might mediate such conflicts, though the issue of trust remains a central element to overcome through wise communication [12].

Coastal integrated management case studies are another example from the research, identifying the need for communication as an instrument for the integration of sectors, levels and local players in the municipality. While analysing North Kurzeme municipalities (the Dundaga case particularly) and using the action research approach through participating in Latvian Coastal Municipalities association discussions, we conclude that there is a drastic mistrust and sectoral thinking paradigm negatively influencing integrated coastal management in Latvia. We believe that integration shall be built on numerous positive collaboration and environmental communication examples which prove that different interests (state nature protection interests, sea shore management for recreation by local business, indigenous people interest for peaceful and traditional life style, land owners and developers, farmers, culture groups, tourism organizations, state forest interests, planners etc.) might be reconciled if collaboration at the local level is enhanced. Mediation of this process shall preferably be coordinated by the local municipality as a central player (not a passive participant), thus increasing its political profile and credibility. Access to qualitative information, tools for participation, involvement of marginalized stakeholders (women, elderly people, and minority groups), real environmentally friendly behaviour examples creating a winwin situation, continuous involvement in education and transfer of knowledge and best practices are crucial elements to build communication instruments for integration. A lack of the comprehensive use of all communication components and neglecting any interests or target groups may lead to a snowball effect in miscommunication and distrust.

As regards the above described NVBR case, its additional value is in enhancing new approaches for integrative planning, done through a landscape ecological planning framework. Though as an innovative approach it was more expensive, and it needed financial support from the Global Environmental Facility (GEF) to build capacities and involve experts able to coordinate processes among so many interest groups. The results are positive and besides the extensive use of communication tools to raise awareness about the new type of plan, training was provided to local planners and forest service specialists, as well as land owners to be able to use the plan in their work. This landscape ecological plan has been implemented as a cooperative effort and based on an exclusively strong communication strategy implemented for the particular planning exercise.

Therefore, we may conclude that the examples existing in Latvia are promising for the implementation of our idea to use communication as an instrument for environmental integration, which might replace even the need for setting up regulatory instruments, the effectiveness of which might be doubtful. We are convinced that environmental policy integration shall be based on informed, skilled and aware participants of the process.

\section{CONCLUSIONS}

Our research findings allow us to draw the following main conclusions:

1. The processes of municipal environmental management and EC development are influenced by several external driving forces: international and EU level sustainable development initiatives, society democratization processes, public management modernization, new environmental management instruments, and national legislation; and bottom-up forces formed by the local public environmental concerns, self-organization potential, and the readiness of society; s stakeholder groups to take part in the environmental management processes at the local level.

2. External driving forces did not have the same quality of impact on environmental management and environmental communication development in municipalities of Latvia. Important pre-requisites for innovation diffusion is knowledge and skills transfer to be implemented through participation in cooperation networks, initiatives and projects developing new management practices necessary to meet challenges posed by the decentralization of environmental governance.

3. Environmental communication as a management instrument is shaped in the concrete local context, and is characterized by the culture and policy style. Important internal factors for EC development include: personal motivation of municipality's staff, political support from the higher level, allocation of resources, existence of institutional mechanisms (environmental specialist, PR position, public consultative boards etc.), as well as a wider spectrum of activities performed by the different local stakeholders (business, NGOs, schools, media, regional agencies etc.), all together forming municipal communication medium and content.

4. External and internal factors interact and establish necessary prerequisites for environmental management integration into municipal development processes. 
Traditionally, environmental integration is ensured through planning instruments and public participation tools. Due to the strong sectoral management paradigm prevailing in society, it is important to create communication platforms to overcome traditional sectoral thinking boundaries at all governance levels. Thus, the development of EC instruments is an essential task.

5. Municipalities in Latvia select different approaches for environmental management: disciplinary, integrative, and mixed. Disciplinary environmental management allows implementing a full-scale management cycle from situation assessment and problems setting to planning, implementation and evaluation. It is a precondition for effective environmental integration in municipal development and planning system. The lack of a complete disciplinary understanding might be levelled by increased communication efforts.

6. Communication and collaboration are widely recognized elements of democracy, as well as pre-conditions for vertical and horizontal integration at the national and local levels.The lack of such elements is a cause for mistrust, which can accumulate through conflicts and jeopardize local development.

7. Understanding the role of EC and communication in general is a relatively new experience in Latvian municipalities, which might be expanded in the near future with better application of modernization concepts (accessibility, inclusiveness, IT) and new government communication guidelines, including the use of market communication instruments, as it has been demonstrated by a couple of the larger municipalities (Ventspils, Liepaja).

8. Communication in the environmental sector that is primarily formally regulated by access to information and participation legal acts, has great potential, if an immense variety of well developed and continuously emerging new environmental communication forms represented by different sectors and target groups, are utilized for the common goal of sustainable development. The synergy effect can be created when formal processes by local governments and public bodies (top-down communication) are supplemented by non-formal processes growing from bottom-up initiatives.

9. To integrate environmental management into municipal development, it is necessary to establish a complementary set of policy instruments, that we suggest might be better enabled by the wise use of all environmental communication components or instruments (environmental information, education, public participation and environmentally friendly behaviour) in their interactivity. Complementarity of EC instruments and stakeholder groups efforts forms synergy and enhances environmental policy and sustainable development prerequisites, namely public environmental awareness, a shift in the environmental thinking of society, and change of consumer society behaviour, production and consumption models.
10. Finally we emphasize that environmental integration starts internally in municipal administration. The collaborative communication shall be developed internally in municipal administration units and its subordinated structures (communal services, tourism agency etc.), as well as externally- in the whole municipal territory and even at the level of ecosystems (river basin, nature protected area) extending municipal boundaries, thus posing a communication imperative in stakeholders relationships.

\section{REFERENCES}

1. Quarrie, J. (ed.) Earth Summit '92. The United Nations Conference on Environment and Development, Rio de Janeiro 1992, The Regency Press Corporation, UK, 1992.

2. Lagzdina, E., Ernsteins, R. Environmental policy planning in urban municipalites Proceedings of the 7 th International scientific and practical conference "Environment, Technology, Resources', June 2527, 2009, Rezekne, Latvia, Rezekne Higher Education Institute, 2009, pp.134.-144 (in Latvian).

3. Second Local Agenda 21 Survey, ICLEI, Freiburg 2002.

4. Ernsteins, R., Kursinska, S., Stals, A., Zilniece, I., Rudzite-Grike, M., Lagzdina, E. Environmental Management Integration into Municipal Development Process: Collaboration Communication Imperative. In Proceedings of the $3 \mathrm{rd}$ international scientific conference A.Livinina (ed.), „Solutions on Harmonizing Sustainability and Nature Protection with Socio-Economic Stability", August 19-20, 2010, Valmiera, Vidzeme University of Applied Sciences, 2010. pp. 53-63.

5. Kursinska, S., Zilniece, I., Ernsteins, R. Integrated environmental communication for sustainable development management at municipalities: target groups development and collaboration. Proceedings of the $8^{\text {th }}$ international scientific methdological conference "Man and environment", May 21-22, 2009, Liepaja University, Liepaja, 2009. pp. 89-93 (in Latvian).

6. Water - A Shared Responsibility. The United Nations World Water Development Report 2, UNECSO, 2006,

7. Working Party on National Environmental Policies: Making Reform Happen in Environmental Policy ENV/EPOC/WPN EP(2009)4/FINAL. 17.11.2009.) OECD, 2009.

8. Bemelmans-Videc, M.S., Rist, R.C., Vedung E. (eds.) Carrots, Sticks, and Sermons: Policy Instruments and Their Evaluation. Transaction Publishers, 2003.

9. Kiss, C., Poltimae, H., Struminska, M., Ewing, M. Environmental Democracy. An Assessment of Access to Information, Participation in Decision-making and Access to Justice in Environmental Matters in Selected European Countries, The Access Initiative, EMLA, Budapest, 2006.

10. Vanags, E., Vilka, I. Municipal operation and development. University of Latvia, Akademiskais apgads, Riga, 2006 (in Latvian).

11. Agenda for the Baltic Sea Region. Sector Report-Education (Baltic 21E). Baltic 21. Series 02/2002, Stockholm: Baltic 21 Secretariat, Ministry of Environment, 2002.

12. Lagzdina, E., Brizga, J. Integration and collaboration as drivers for local sustainability: North Kurzeme case. In Grasserbauer M. et al (eds.) „Knowledge-Based Technologies and OR Methodologies for Strategic Decisions of Sustainable Development", Vilnius Technika, 2009, pp. 80-84

\section{E. Lagzdina, director}

The Regional Environmental Center for Central and Eastern Europe

Country Office in Latvia

Address: Riga, Peldu Str. 26/28, LV-1050

Phone: +371-26551438

E-mail:erika.lagzdina@reclatvija.lv

Ērika Lagzdiṇa. Vides komunikācijas instrumenti vides politikas integrācijai

Raksta pamatu veido divi populāri pārvaldības koncepti: pārvaldības modernizācija un vides pārvaldības (politikas) integrācija, kurus autore piedāvā apvienot, izmantojot vides komunikācijas instrumentus, lai tā veicinātu ilgtspējīgu attīstību vietējā, t.i., pašvald̄̄bu līmenī. Vides pārvaldības pieredzes veidošanos Latvijā pēdējos 20 gadus ietekmē ārējo spēku (ilgtspējīgas attīstības process, sabiedrības demokratizācija, integrācija ES, jaunu politikas 
instrumentu ieviešana u.c.) un iekšējo faktoru (vietējās sabiedrības vides apziṇas, pašorganizēšanās potenciāls, politiskais atbalsts, speciālistu motivācija u.c.) mijiedarbība. Šī mijiedarbība veido vietējā līmen̦a vides komunikācijas procesu, kurā tiek pārstāvēti dažādi pārvaldības līmeṇi un interešu jeb mērķa grupas. Vides komunikācijas (VK) instrumentu attīstībai ir tieša saikne ar vides pārvaldības attīstības līmeni pašvaldībā. Disciplinārās vides pārvaldības pieredze pozitīvi ietekmē gan VK, gan arī vides mērku integrāciju visā pārvaldības procesā, tā ir veicinošs faktors kvalitatīvai integrētas politikas izstrādei, kas ir aktuāls izaicinājums gan pilsētu pašvald̄̄bām, gan aizsargājamām dabas teritorijām un arī jūras piekrastes apsaimniekošanai. Atzīstot, ka tieši plānošanas instrumentu izmantošanai ir vislielākā ietekme uz integrāciju, mēs pētījumā meklējām iespējas plānošanas procesu uzlabošanai ar vides komunikācijas instrumentu palīdzību, uzsvaru liekot uz sadarbību starp dažādām mērḳa grupām vietējā līmenī. Daudzveidīgā, lai gan ne sistemātiskā prakse Latvijā, apkopojot 30 situāeijas un intervējot vairāk kā 70 speciālistus, l̦auj identificềt pietiekamu VK elementu kopumu un pārvald̄̄bas procesu piemērus, kas l̦auj apgalvot, ka vides komunikācija var veidot noslēgtu pārvaldības ciklu un tādejādi kā patstāvīgs vides pārvaldības sektors gan ir integrējama pašvaldības attīstībā, gan arī izmantojama kā instruments vides politikas integrācijai.

Эрика Лагздиня. Инструменты экологической коммуникации для интеграции экологической политики

В основе написания статьи лежат две популярные концепции управления: модернизация управления и интеграция экологического менеджмента (политики), которые мы предлагаем объединить с помощью использования экологических коммуникационных инструментов для содействия долгосрочному развитию на местном уровне, т.е. уровне самоуправлений. На опыт развития экологического менеджмента в Латвии в течение последних 20 лет влияло взаимодействие внешних (процесс долгосрочного развития, демократизация общества, интеграция в ЕС, введение новых политических инструментов и пр.) и внутренних факторов (экологическое сознание местного общества, потенциал способности самоорганизовываться, политическая поддержка, мотивация специалистов и пр.). Это взаимодействие создает процесс экологической коммуникации на местном уровне, в котором представлены разные уровни управления и разные группы интересов или целевые группы. Развитие инструментов экологической коммуникации тесно связано с уровнем развития экологического менеджмента в самоуправлении. Наличие опыта дисциплинарного экологического менеджмента позитивно влияет на экологическую коммуникацию и на интеграцию экологических целей в процесс управления; это фактор, содействующий разработке качественной интегрированной политики, что является актуальным вызовом и для городских самоуправлений, и для охраняемых природных территорий, и для управления приморских территорий. Признавая, что именно использование инструментов планирования имеет наибольшее влияние на интеграцию, в своём исследовании мы искали возможности для улучшения процесса планирования с помощью инструментов экологической коммуникации, особенно концентрируясь на сотрудничестве между различными целевыми группами на местном уровне. Проведение многообразной, хотя и не систематической практики в Латвии, в рамках которой было обобщено 30 ситуаций и проведено более 70 интервью со специалистами, позволило идентифицировать достаточную совокупность элементов экологической коммуникации и примеров процессов управления. Полученные результаты позволили произвести утверждение о том, что экологическая коммуникация может образовать закрытый цикл управления и таким образом постоянный сектор экологического менеджмента может быть интегрирован в развитие самоуправления и использован в качестве инструмента для интеграции экологической политики. 